\title{
Self-Organisation Perspective to Responsible Innovation in Industry
}

Based on scientific literature analysis, the article examines the complex nature of the responsible innovation concept and provides the conceptual integration of a self-organisation perspective into the concept of responsible innovation within industry. Self-organisation characteristics are presented and argued as useful constructs for a better understanding of responsible innovation processes.

Keywords: responsible innovation, self-organisation, complexity, industry.

Remiantis moksline literatūros analize, straipsnyje siekiama apžvelgti kompleksišką atsakingụjų inovacijų sampratą, pristatyti saviorganizacijos sampratą ir pagrindinius komponentus bei konceptualiai pagrịsti saviorganizacijos perspektyvos taikymą atsakingosioms inovacijoms industrijoje nagrinèti.

Raktiniai žodžiai: atsakingosios inovacijos, saviorganizacija, kompleksiškumas, industrija.

\section{Introduction}

Innovation as a phenomenon is a highly complex and creative process. The way how and to what direction innovation is developed within the firm heavily depends on the societal context the firm is embedded in. Firms are constantly adapting their innovative behaviour based on the emerging social norms and the industrial environment (Buenstorf, 2000; Pyka, Windrum, 2003). Therefore, in this paper, innovation is understood as an evolutionary process interacting with the social context.

Currently, changes are seen towards the arising awareness to the grand challenges, i.e., global societal, ecological, economic and ethical issues, like social inequality and discrimination, sustainable development, climate change (Lund Declaration, 2009). Innovation also plays a role in this context, because its outcomes can positively or negatively affect the environment and society, thus contributing to the grand challenges (Owen, Bessant, Heintz, 2013). However, the responsibility is shared among the firms and societal members and only collective action can mitigate the grand challenges (von Schomberg, 2013). In this context, the concept of responsible innovation emerged in order to search for solutions and more responsible development of innovation

\footnotetext{
Jolita ČEIČYTÉ - PhD Candidate at the Department of Strategic Management, School of Economics and Business, Kaunas University of Technology. Address: Gedimino st. 50, LT-44309, Kaunas, Lithuania. Phone: +370 37300121. E-mail: jolita.ceicyte@ktu.lt
}

Monika PETRAITE - doctor of social sciences, professor at the Department of Strategic Management, School of Economics and Business, Kaunas University of Technology. Address: Gedimino st. 50, LT-44309, Kaunas, Lithuania. Phone: +370 373001 21. E-mail: monika.petraite@ktu.lt 
(Lubberink et al., 2017). Since firms play a key role in innovation commercialization, it is crucial to search for solutions how firms can include wider society into the innovation process and make a positive contribution into society and the environment (Berkhout, 2014; Scholten, Blok, 2015).

In this context, the concept of responsible innovation emerged and has been studied by a variety of scholars (Helstrom, 2003; Owen, 2009; Sutcliffe, 2011; Armstrong, et al., 2012; Owen, Bessant, Heintz, 2013; Pandza, Ellwood, 2013; Stahl, 2013). The notion of responsible innovation has caught important attention in recent research on innovation management recognizing its role in a long-term success (Owen, Macnaghten, Stilgoe, 2012; Pavie, Scholten, Carthy, 2014; Scholten and Blok, 2015). Responsible innovation is suggested as a new approach to innovation governance taking into account the socioethical aspects of innovation towards society and the environment, also by involving wider society into the innovation process (von Schomberg, 2013; Stilgoe, Macnaghten, Owen, 2013). At the same time, responsible innovation is a complex concept that includes different stakeholders of society, requires coordinated actions of various stakeholders, implementation of new ideas, activities and resources towards mitigating the grand challenges. Responsible innovation as a concept demands a systemic view and understanding.

The current nature and components of the concept of responsible innovation correlates well with a self-organisation perspective. Self-organisation is an emergent process consisting of multiple agents and their non-linear interactions (Grumadaite, Jucevičius, 2017). Self-organisation captures the interconnectedness of different stakeholders that cause complex evolution of new routines, processes and emergence of standards (Buenstorf, 2000). Therefore, the self-organisation perspective is useful to understand the complex nature of responsible innovation in industry. Thus, we attempt to make a theoretical contribution to responsible innovation studies by presenting a relationship between self-organisation and responsible innovation in the private sector.

The research question of this paper is: How a self-organisation perspective could be applied in responsible innovation in industry?

Consequently, the aim of this paper is to reveal the conceptual link between selforganisation and responsible innovation in industry.

The objectives of this paper are:

- To explore the role of a social context of responsible innovation;

- To reveal the complexity of responsible innovation in industry;

- To define and integrate the self-organisation perspective in responsible innovation in industry.

To achieve the objectives of this paper, the method of literature analysis is employed.

\section{The role of social context in responsible innovation}

The social context of a company is formed by society and its reactions to innovations and technological progress (Castells, 2011). Firm's innovation depends on how society reacts to the innovation. There are many reasons and aspects that lead to societal acceptance or rejection regarding the innovation. Some of them are discussed in the following paragraphs. 
First, a possible reason for the rejection of an innovation is society's distrust due to human nature, i.e., sometimes authorities, institutions or firms make decisions without having enough of the competence or all the possible knowledge (von Schomberg, 2013). This is especially relative regarding radical innovation, when there is no previous context or experience about a new product. In the case of innovations, pooling different knowledge and skills can enhance the possibility of forecasting the positive outcomes of an innovation (Palm, Hansson, 2006). However, in such a situation, it is possible that even with the best intentions of innovators to come up with the positive outcomes, some negative aspects of innovation might arise after its commercialisation (Grinbaum, Groves, 2013; Grunwald, 2014). In most cases, innovators are just not capable of anticipating all the possible outcomes of an innovation. Moreover, there are cases, when the innovative product was used for a negative purpose by other societal members, for example, the dynamite, and the innovator could not forecast such a radically different use of the innovation.

Second, innovators and/or employees working at firms are citizens themselves, and should act in such a way as they were the end consumers of what they develop and commercialise into the market (Pavie, 2012). However, the reality is that there are many cases when firms fail in developing innovations in a responsible manner, and individuals, who belong to a firm, are constrained by corporate contracts and affraid of losing jobs or financial status. Thus, the innovation process is complex and sistematic, involving different actors and affecting the whole ecosystem. This situation could be described as "organised irresponsibility” (Beck, 1997). Therefore,
R. Owen et al. (2013) suggest that it is nesecary to share the responsibility in order to achieve more positive outcomes of an innovation.

Also, companies start to show some motivation for developing innovation in a more responsible manner, taking into account not only internal organisational responsibility, but the external as well, which concerns society and the environment (Čeičytè, Petraité, 2014). On the one hand, organisations are forced to integrate the higher level of responsibility, because this is part of being competitive among other organisations. On the other hand, firms seek for the trust of society, since its norms and requirements are changing towards more responsible behaviour (von Schomberg, 2013). According to B. C. Stahl (2013), organisations must have their fundamental normative principles by seeking to evaluate if the developing innovation is acceptable for society.

Although innovation is usually regarded as a positive source of the economy, T. Hellstrom (2003) notes that society faces the problem of modernity by focusing only on the techno-economic progress instead of developing innovation upon the normative principles. Therefore, negative aspects of the innovation are remaining mostly unnoticed. Possible negative consequences of the innovation can increase the so-called grand challenges that include social inequality and discrimination, sustainable development, climate change, etc. (Lund Declaration, 2009). As the grand challenges are caused by multiple and complex actions of societal members, including firms, these global problems are difficult to manage and mitigate. Therefore, the grand challenges are also referred as "wicked problems" (Rittel, Weber, 1973). Furthermore, there is a need 
to integrate a wider range of the related stakeholders into the innovation development in order to foresee possible negative consequences of the innovation (Stilgoe, 2013). This would allow to holistically develop the innovation towards the benefit of society and the environment and society would have a possibility to participate in the innovation process, which could lead towards the societal acceptance of an innovation. Thus, the concept of responsible innovation that has emerged it is important to explore in this context.

\section{The complexity of responsible innovation in industry}

The concept of responsible innovation emerged as a need to assess and govern controversial socio-ethical aspects of emerging technologies like nanotechnologies, big data, genomics, etc. (Scholten, Blok, 2015). Responsible innovation can be defined as a new approach to innovation governance taking into account the ethical acceptability, sustainability and societal desirability of innovations (von Schomberg, 2013). Responsible innovation is defined as "a transparent, interactive process by which societal actors and innovators become mutually responsive to each other with a view to the (ethical) acceptability, sustainability and societal desirability of the innovation process and its marketable products (in order to allow a proper embedding of scientific and technological advances in our society)" (von Schomberg, 2013, p. 9). Since longterm effects of innovation are notoriously difficult to predict, responsible innovation is being used as a framework to mitigate the unintended negative consequences of innovation by including related stake- holders into the innovation process of the firm (Blok, Lemmens, 2015).

The question is then how a company can make use of the responsible innovation concept in its innovative practice? In literature on responsible innovation, there are few different approaches to development of the framework of responsible innovation. Some scholars suggest technology assessment (Hellström, 2003; von Schomberg, 2012a; Grunwald, 2014), value sensitive design (van den Hoven, 2013), design thinking (Pavie and Carthy, 2013).

However, the most dominant in the responsible innovation literature (Burget, Bardone, Pedaste, 2017) is the AIRR framework proposed by R. Owen, P. Macnaghten and J. Stilgoe (2012). They suggested the four responsible innovation dimensions, such as anticipation, inclusion, reflexivity and responsiveness. Each principle raises its own specific questions which help to assure that ideas are examined in a broader perspective towards responsible innovation. The first dimension is anticipation, which is defined as involving "systematic thinking aimed at increasing resilience, while revealing new opportunities for innovation and the shaping of agendas for socially-robust risk research" (Stilgoe, et al. 2013, p. 1570). Inclusion of various stakeholders is important offering more opportunities to solutions when dealing with the grand challenges (Cagnin, Amanatidou, Keenan, 2012) and sharing different, maybe even opposing opinions, combining contrasting interests, etc. (Blok, Hoffmans, Wubben, 2015). Reflexivity, the third dimension of responsible innovation, is determined as institutional and scientific practice, which is "holding a mirror up to one's own activities, commitments and assumptions, 
being aware of the limits of knowledge and being mindful that a particular framing of an issue may not be universally held" (Stilgoe et al., 2013, p. 1753). The last dimension, responsiveness, is about being capable of changing or shaping the direction of an innovation in response to values of stakeholders and wider society (Lubberink et al., 2017).

The aforementioned responsible innovation dimensions also reflect the need to have a systematic view for the concept of responsible innovation. Firms are interconnected with society, and basically act as complex adaptive systems (McKelvey, 2001, Plowman et al., 2007). If a traditional approach to innovation is changing from mechanistic towards a complex view, then the responsible innovation concept integrates and demands even more complexity. As R. von Schomberg (2013) suggests, firms should integrate stakeholders and become mutually responsive to each other. This means that the firm's innovation process is shared with the firm's stakeholders, therefore, they should evolve into one system. Although in the responsible innovation literature it is required to include non-economic stakeholders like citizens, public groups, etc., firms are already intensively including their partners and suppliers, or are involved in clusters and associations that usually represent economic stakeholders. Since firms have skills of including economic stakeholders, it is important to understand how they can be motivated to include noneconomic stakeholders, as well and how it could be understood as a positive action. Since innovations are driving most of the economies, it is possible that innovating firms are involving in self-organisational processes with other stakeholders (Biggiero, 2001; Rycroft, Kash, 2004).
The changing societal context towards the awareness of societal, ecological, economic and ethical issues is noticed by companies, because they scan the changes of norms and societal behaviour (Petraite et al., 2017). Firms are constantly experiencing instability and they tend to change their behaviour regarding new challenges that arise in their environment. The more firms are in a higher instability, the more they are capable of changing their behaviour (Plowman et al., 2007). Such the endogenous and exogenous co-evolution is referring to the phenomenon of selforganisation. Self-organisation is most noticed in inter-organisational collaborative activities in highly complex sectors like bioengineering, aircraft or telecommunications (Rycroft, Kash, 2004). Such collaborative innovation networks "are able to combine new scientific and technological capabilities and recombine old ones without the intervention of a central controller" (Rycroft, Kash, 2004, p. 187), therefore, these collaborative networks have experience and further potential to self-organisation. In the following section, the connection of responsible innovation and self-organisation is analysed.

\section{Self-organisation perspective application in responsible innovation}

Acoording to G. Buenstorf (2000, p. 126), self-organisation is seen as a "process of emergent order at the system level generated by the non-linear interaction of the system components. In turn, macro-level properties influence the components' behavior". The fundamental research question that studies in the self-organisation field seek to answer is "Where does order 
come from?" (Pyka, Windrum, 2003). At the systemic level emerge new structure and order that primarily are based on the system's components (agents) interactions without centralised control (Allen, Lesser, 1991). The interaction of interdependent agents of the system is described by information exchange, taking actions and continuous adaption to the feedback about other's action instead of conforming to centralised control (Chiles, Meyer, Hench, 2004). Because agents act upon new emerging properties and structures that are new and unplanned, agents come up with new solutions and processes (Plowman et al., 2007). Such an interaction between agents gives ability for a system to co-evolve. A self-organising system distinguishes itself by a clear sense of identity, norms and culture. The most important indicators for a self-organising system is high level of confidence and co-operation, open and transparent communication. Regarding responsible innovation, transparency is one of the key characteristics.

It is important to achieve common collective behaviour, otherwise, chaotic behaviour can dominate. Collective behavior is described by the fitness. In the self-organising system, agents are coevolving by improving their fitness regarding the environment. Therefore, the fitness is based on the decisions of other agents in the self-organising system. It is crucial for agents to avoid self-pragmatism and self-interest. Such egoistic behaviour would have a negative impact on the whole self-organising system, because they start to compete instead of co-operating. Thus, the self-organisation framework helps to describe and understand the development processes of complex systems (Buenstorf, 2000).
The self-organization perspective gives an opportunity to understand the complex behavior of the firm and how the firm interacts with the environment, which consists of culture, norms and institutions (Buenstorf, 2000). Also, self-organisation emphasizes "the heterogeneity of firms, the rules that govern their individual behaviour, and the rules governing the interaction between firms" (Pyka, Windrum, 2003, p. 247). Therefore, regarding responsible innovation, if one firm or a related stakeholder starts to implement responsible innovation, this act influences other firms as well.

How the characteristics of self-organisation can enhance the understanding about responsible innovation? In this paper, disequilibrium state, non-linearity of interactions, positive and negative feedbacks, and emergence are used to better understand how responsible innovation could be employed in industry.

Disequilibrium state. The more the system is not disturbed, the more higher level of order appears (Buenstorf, 2000). Disequilibrium state means that the system is disturbed by the micro-level agents (Allen, Lesser, 1991). They are creating tensions (Uhl-Bien, Marion, McKelvey, 2007) or triggers that include new ideas, information, activities, resources, etc. (Chiles et al., 2004). Regarding responsible innovation in industry, the current system is experiencing disequilibrium state, because of the changing norms of society towards responsibility. New ideas about how innovation should be processed, what should be the outcomes of the innovation are disturbing the way how the industrial system currently works. The institutional context also plays a role by creating new policy incentives towards mitigating the grand challenges. Therefore, new activities 
and resources are required to implement into the firm's innovative activities to meet the new social context. However, new ideas, activities and resources are explored and implemented in a selforganising system that usually have an entity responsible for the system's core capabilities and new direction of innovative activities. In this system, firms are transferring new behaviour into their own innovation activities (Rycroft, Kash, 2004). For responsible innovation, it means that a firm or any kind of organisation should come up with new ideas how to adapt to the new societal requirements and form a self-organising network in which firms and different stakeholders should develop and implement new innovation practices towards mitigating the grand challenges and including wider society from the ideation phase.

Non-linearity of interactions. In the self-organization literature, non-linearity appears in multiple interactions among the actors of a system. These interactions appear from time to time, including numerous feedback loops. Positive and negative feedback loops exist among the actors of the system, between lower and higher hierarchical levels (Pyka, Windrum, 2003). Non-linearity of interactions shows the ability to connect the actors and evolve into a one self-organising system. This characteristic is also relative to the responsible innovation process. It combines multiple interactions among different stakeholders of society. Firms with stakeholders should be able, however, to interact and evolve together towards responsible innovation.

Positive and negative feedback. Through the feedback loop the self-organising system is able to reorganise itself into a new structure (Buenstorf, 2000). Sur- prisingly, negative feedback is more useful than positive, and it correlates with responsible innovation as well. The positive feedback helps a self-organising system to lock-in into specific paths. For some of the time lock-in situation helps the selforganising system to maintain advantage by being a standard in the market. Usually, positive feedback leads to an emergence (Pyka, Windrum, 2003), which is described in the following paragraph. Since the positive feedback mechanism exists, the self-organising system is only evolving from the inside, i.e., the feedback from the outside is not making an impact on the system anymore. Therefore, positive feedback can lead to the edge of chaos, because the system becomes closed and not developing itself anymore by including new ideas and activities (Buenstorf, 2000). Therefore, negative feedback is playing a crucial role by helping a selforganising system to avoid chaos and constantly develop itself and evolve. Eventually, self-organisation is a mix of positive and negative feedback (Buenstorf, 2000). Regarding responsible innovation, negative feedback is also emphasized by including stakeholders with their opposing opinions regarding innovation. Thus, inclusion of wider society into the firm's innovation processes can lead to critical situations with negative feedback, but at the same time, a firm could avoid a chaotic situation. When a firm tries to avoid negative feedback and only seeks for positive feedback, it cannot evolve and adapt to the new environment.

Emergence. As mentioned earlier, the positive feedback is leading to the emergence of some specific new behaviour or standards that a self-organising system established. Emergence is a bottom-up situation, when agents from a micro-level get 
the positive feedback to their newly established ideas and actions (Pyka, Windrum, 2003). Positive feedback gives a confirmation to a self-organising system that they are adequate to the new environment with their actions. The emergence of new behaviour of the self-organising system leads to the institutionalisation, which is expressed by tagging mechanisms, i.e., new brands, symbols, certificates, etc. The tagging mechanisms reveal the new order and identity, through which certain cultural behavior and norms are revealed to society (Witt, 1987). Thus, micro-level initiative can become a new standard at the macro-level (Pyka, Windrum, 2003). The existing tagging mechanisms currently include some of the practices related to responsible innovation, like corporate social responsibility (CSR), cradle to cradle, sustainable development, etc. Societal members and firms self-organised into a system with the goal to reflect the existing issues and develop new standards. In case of responsible innovation, currently, many initiatives arise from the European Commission (European Commission, 2008; 2011; 2012). Therefore, it is important to better align the concept of responsible innovation with the industry (Scholten, Blok, 2015), so that firms could also contribute to the new self-organising process towards responsible innovation within each firm.

\section{Conclusions}

In this paper, the perspective of self-organisation was employed in responsible innovation in industry. Due to the complexity of the concept of responsible innovation in industry, self-organisation seems to be a suitable approach to better under- stand how responsible innovation could be implemented in the firms' innovative practice. In this paper, four characteristics (disequilibrium state, non-linearity of interactions, positive and negative feedback, and emergence) of self-organisation were analysed in terms of responsible innovation in industry. Disequilibrium state revealed the possibility for responsible innovation to emerge in firms' practice. The changing societal context towards mitigating the grand challenges is leading firms to the disequilibrium state. Therefore, firms have to self-organise into new clusters or networks, which could help to better understand the urgent matter for more responsible practice in innovation development. Via a self-organising system that includes both firms and related stakeholders, new ideas and practices reflecting responsible innovation concept could be implemented in firms' innovative activities. Non-linearity of interactions reflects the multiple and interactive nature of agents of the system. This characteristic helps to better understand how firms and their stakeholders are interconnected, and reveals the need to integrate stakeholders into the responsible innovation processes within the firm. The included stakeholders are crucial for their positive and negative feedback. The positive feedback of stakeholders regarding responsible innovation can lead into the emergence of newly established practices and cultural norms within the self-organising system. If responsible innovation became a new standard among self-organising firms and stakeholders, this standard would be followed by other firms as well. But the negative feedback of stakeholders is even more important, because of the critical insights of stakeholders towards the firm's innovation. The negative feedback of 
included stakeholders can help to sustain a continuous improvement and adaptation to changes in the environment, therefore constantly reflects the issues and evolve towards the right direction, in this case, towards the implementation of responsible innovation within the firm.
The paper was prepared with the support of the Research Council of Lithuania under the research project "Enabling the self-organization in contemporary innovation ecosystems: perspective of latecomer economy" (grant no. MIP018/2015).

\section{References}

1. Allen, P. M., Lesser, M. (1991). Evolutionary Human Systems: Learning, Ignorance and Subjectivity // In Evolutionary Theories of Economic and Technological Change, eds. P. P. Saviotti, J. S. Metcalfe. - Chur: Harwood Academic Publishers, p. 160-171.

2. Armstrong, M., Cornut, G., Delacôte, S., Lenglet, M., Millo, Y., Muniesa, F., Tadjeddine, Y. (2012). Towards a Practical Approach to Responsible Innovation in Finance: New Product Committees Revisited // Journal of Financial Regulation and Compliance. Vol. 20, No. 2, p. 147-168. doi: 10.1108/13581981211218289.

3. Beck, U. (1992). Risk Society: Towards a New Modernity. - Sage.

4. Berkhout, F. (2014). Sustainable Innovation Management. Innovation and Sustainability // In The Oxford Handbook of Innovation Management, ed. M. Dodgson, D. M. Gann, N. Phillips. - Oxford: University Press, p. 290-315.

5. Biggiero, L. (2001). Self-organizing Processes in Building Entrepreneurial Networks: A Theoretical and Empirical Investigation // Human Systems Management, Vol. 20, No. 3, p. 209-222.

6. Blok, V., Hoffmans, L., Wubben, E. F. M. (2015). Stakeholder Engagement for Responsible Innovation in the Private Sector: Critical Issues and Management Practices // Journal on Chain and Network Science. Vol. 15, No. 2, p. 147-164. doi: 10.3920/JCNS2015.x003.

7. Blok, V., Lemmens, P. (2015). The Emerging Concept of Responsible Innovation. Three Reasons why it is Questionable and Calls for a Radical Transformation of the Concept of Innovation / In Responsible Innovation Vol. 2, p. 19-35. Springer International Publishing. doi: 10.1007/978-3-319-17308-5_2.

8. Scholten, V. E., Blok, V. (2015). Foreword: Responsible Innovation in the Private Sector //
Journal on Chain and Network Science, Vol. 15, No. 2, p. 101-105. doi: 10.3920/JCNS2015.x006.

9. Buenstorf, G. (2000). Self-organization and Sustainability: Energetics of Evolution and Implications for Ecological Economics // Ecological Economics, Vol. 33 No. 1, p. 119-134.

10. Burget, M., Bardone, E., Pedaste, M. (2017). Definitions and Conceptual Dimensions of Responsible Research and Innovation: A Literature Review // Science and engineering ethics, Vol. 23, No. 1, p. 1-19.

11. Cagnin, C., Amanatidou, E., Keenan, M. (2012). Orienting European Innovation Systems towards Grand Challenges and the Roles that FTA can Play // Science and public policy, Vol. 39, No. 2, p. 140-152. doi:10.1093/scipol/scs014.

12. Castells, M. (2011). The Rise of the Network Society. The Information Age: Economy, Society, and Culture (Vol. 1). - John Wiley \& Sons.

13. Čeičytè, J., Petraitė, M. (2014). Atsakingųjų inovacijų koncepcija // Viešoji politika ir administravimas. T. 13, Nr. 3, p. 400-413. doi: 10.5755/j01.ppaa.13.3.8302.

14. Chiles, T. H., Meyer, A. D., Hench, T. J. (2004). Organizational emergence: The origin and transformation of Branson, Missouri's musical theaters // Organization Science, Vol. 15, No. 5, p. 499-519.

15. Dodgson, M., Gann, D. M., Phillips, N. (2014). Perspectives on Innovation Management / The Oxford Handbook of Innovation Manage-ment. - Oxford: University Press, p. 3-25.

16. European Commission (2008). European Cmmissions Code of Conduct for Responsible Nanotechnologies Research. Internet access: <http://ec.europa.eu/nanotechnology/pdf/ nanocode-rec_pe0894c_en.pdf $>$ [accessed September 3, 2017]. 
17. European Commission (2011). DG Research Workshop on Responsible Research and Innovation in Europe. Internet access: <http:// ec.europa.eu/research/science-society/ document_library/pdf_06/responsibleresearch-and-innovation-workshop-newsletter_ en.pdf $>$ [accessed September 3, 2017].

18. European Commission (2012). Responsible Research and Innovation: Europe's Ability to Respond to Societal Challenges. Internet access: <https://ec.europa.eu/research/swafs/pdf/ pub_rri/KI0214595ENC.pdf $>$ [accessed September 3, 2017].

19. Grumadaite, K., Jucevičius, G. (2017). Preconditions for Emergence of Lithuanian Clusters: From Informal Cooperation to Its Legitimation // Management of Organizations: Systematic Research, Vol. 77, No. 1, p. 37-56. doi: 10.1515/mosr-2017-0003.

20. Grunwald, A. (2014). Technology Assessment for Responsible Innovation. In Responsible Innovation 1, p. 15-31. - Springer Netherlands.

21. Hellstrom, T. (2003). Systematic Innovation and Risk: Technology Assessment and the Challenge of Responsible Innovation // Technology in Society. Vol. 25, p. 369-384. doi: 10.1016/S0160791X(03)00041-1.

22. Lubberink, R., Blok, V., van Ophem, J., Omta, O. (2017). Lessons for Responsible Innovation in the Business Context: A Systematic Literature Review of Responsible, Social and Sustainable Innovation Practices // Sustainability, Vol. 9, No. 5.

23. Lund Declaration (2009). Konferencija: Nauji pasauliai - naujos išeitys. Moksliniai tyrimai ir inovacijos kaip pagrindas Europos vystymuisi globaliame kontekste. Lundas, Švedija, 7-8 Liepa, 2009. Internet access: <http://www.se2009. eu/polopoly_fs/1.8460!menu/standard/file/ lund_declaration_final_version_9_july.pdf $>$ [accessed September 15, 2017].

24. McKelvey, B. (2001). What is Complexity Science? It is Really Order-Creation Science // Emergence, A Journal of Complexity Issues in Organizations and Management. Vol. 3, No. 1, p. 137-157.

25. Owen, R. (2009). A New Era of Responsible Innovation. Internet access: <http:// planetearth.nerc.ac.uk/features/story. aspx?id $=460 \&$ cookieConsent $=\mathrm{A}>\quad$ [accessed September 10, 2017].

26. Owen, R., Bessant, J., Heintz, M. (2013). Responsible Innovation: Managing the Respon- sible Emergence of Science and Innovation in Society. - John Wiley \& Sons.

27. Owen, R., Macnaghten, P., Stilgoe, J. (2012). Responsible Research and Innovation: From Science in Society to Science for Society, with Society // Science and Public Policy. Vol. 39, No. 6, p. 751-760. doi: 10.1093/scipol/scs093.

28. Palm, E., Hansson, S. O. (2006). The Case for Ethical Technology Assessment (eTA) // Technological Forecasting and Social Change. Vol. 73, No. 5, p. 543-558. doi: 10.1016/j.techfore.2005.06.002.

29. Pandza, K., Ellwood, P. (2013). Strategic and Ethical Foundations for Responsible Innovation // Research Policy. Vol. 42, No. 5, p. 1112-1125. doi: 10.1016/j.respol.2013.02.007.

30. Pavie, X. (2012). The Importance of Responsible-Innovation and the Necessity of "Innovation-Care”. Internet access: <http://papers.ssrn. com/sol3/papers.cfm?abstract_id=2330132> [accessed September 10, 2017].

31. Pavie, X., Carthy, D. (2013). An Integration of Responsible Innovation in the Financial Sector through Design Thinking. Internet access: <http://hal.archives-ouvertes.fr/ docs/00/92/14/28/PDF/WP1324.pdf > [accessed September 15, 2017].

32. Pavie, X., Scholten, V., Carthy, D. (2014). Responsible Innovation: From Concept to Practice. Singapore: - World Scientific Publishing Co.

33. Petraite, M., Pavie, X., Ceicyte, J., Janiunaite, B., Carthy, D. (2017). Managing Innovation in Multicultural Environments: An Imperative of Responsibility Within Interorganizational Networks. In Intercultural Interactions in the Multicultural Workplace, p. 137-154. - Springer International Publishing.

34. Plowman, D. A., Solansky, S., Beck, T. E., Baker, L., Kulkarni, M., Travis, D. V. (2007). The role of leadership in emergent, self-organization // The Leadership Quarterly, Vol. 18, No. 4, p. 341-356.

35. Pyka, A., Windrum, P. (2003). The Self-Organisation of Strategic Alliances // Economics of innovation and new technology, Vol. 12, No. 3, p. 245-268. doi: 10.1080/10438590290025561.

36. Rittel, H. W. M, Weber (1973). Dilemmas in a General Theory of Planning // Policy Sciences, Vol. 4.

37. Rycroft, R. W., Kash, D. E. (2004). Self-organizing innovation networks: implications for globalization // Technovation, Vol. 24, No. 3, p. 187-197. 
38. Stahl, B. C. (2013). Responsible Research and Innovation: The Role of Privacy in an Emerging Framework. Internet access: <http://spp.oxfordjournals.org/content/early/2013/09/19/scipol. sct067.full.pdf + html $>$ [accessed September 10, 2017].

39. Stahl, B. C., McBride, N., Wakunuma, K., Flick, C. (2013). The Empathic Robot: A Prototipe of Responsible Research and Innovation. Internet access: <https://www.researchgate.net/ publication/261563960_The_empathic_care_ robot_A_prototype_of_responsible_research_ and_innovation $>$ [accessed September 10, 2017].

40. Stilgoe, J. (2013). Foreword: Why Responsible Innovation? / In R. Owen, J. Bessant, M. Heintz (ed.), Responsible Innovation: Managing the Responsible Emergence of Science and Innovation in Society. - John Wiley and Sons, Ltd.

41. Stilgoe, J., Owen, R., Macnaghten, P. (2013). Developing a Framework for Responsible Innovation. Internet access: <http://www.sciencedirect. com/science/article/pii/S0048733313000930> [accessed September 10, 2017].
42. Uhl-Bien, M., Marion, R., McKelvey, B. (2007). Complexity Leadership Theory: Shifting Leadership from the Industrial Age to the Knowledge Era // The Leadership Quarterly. Vol. 18, No. 4, p. 298-318. doi 10.1016/j.leaqua.2007.04.002.

43. Van den Hoven, J. (2013). Value Sensitive Design and Responsible Innovation. / In R. Owen, J. Bessant, M. Heintz (ed.), Responsible Innovation: Managing the Responsible Emergence of Science and Innovation in Society. - John Wiley and Sons, Ltd.

44. Von Schomberg, R. (2013). A Vision of Responsible Innovation. Internet access: <https://europa. eu/sinapse/sinapse/index.cfm? \&fuseaction=lib. attachment\&lib_id=B98F4473-BB94-B4A93B6749A0CC445DFA \&attach=LIB_DOC_ EN> [accessed September 10, 2017].

45. Witt, U. (1998). Imagination and leadership-the neglected dimension of an evolutionary theory of the firm // Journal of Economic Behavior and Organization, Vol. 35, No. 2, p. 161-177.

The paper submitted: October 30, 2017

Prepared for publication: December 10, 2017

\title{
Jolita ČEIČYTĖ, Monika PETRAITÉ
}

\section{SAVIORGANIZACIJOS PERSPEKTYVA ATSAKINGOSIOMS INOVACIJOMS INDUSTRIJOJE}

\author{
S a n t r a u k a
}

Atsakingujų inovacijų ideja ir samprata nagrinèjama daugelio inovacijų srities autorių (Helstrom, 2003; Owen, 2009; Sutcliffe, 2011; Armstrong, Cornut, Delacote ir kt., 2012; Owen, Macnaghten, Stilgoe, 2012; Pavie, 2012; Owen, Bessant, Heintz, 2013; Pandza, Ellwood, 2013; Stahl, 2013; Stahl, McBride, Wakunuma, Flick, 2013). Atsakingujų inovacijų koncepcija nukreipta $i$ inovacijas generuojančių organizacijų poreikị suderinti skirtingų suinteresuotų grupių ir asmenų (angl. stakeholders) interesus vykstant inovacinès veiklos procesui bei siekiant rezultatų. Atsakingujų inovacijų motyvas siekti vartotojams priimtinų, jų sociokultūrines vertybes ir aplinkosaugos orientacijas atitinkančių produktų, tačiau taip pat norima išvengti inovacijų socioetinès, aplinkosauginès ir ekonominès rizikos. Atsakingųjų inovacijų tyrimai koncentruojami ị subalansuotą inovacijų kūrimo procesą, siekiant pozityvių inovacijos rezultatų visuomenès ir aplinkos atžvilgiu ilgalaikeje perspektyvoje pasitelkiami ir socioetiniai aspektai (von Schomberg, 2013; Blok, Lemmens, 2015, Čeičytè, Petraitè, 2015).

Atsakingųjų inovacijų tyrimams reikalingas sisteminis požiūris, nes atsakingųjų inovacijų samprata ir tikslai keliami sisteminiu principu, t. y. siekiant teigiamų inovacijos rezultatų, inovacijų procese suvienijami skirtingi veikejai (Dodgson, Gann ir Phillips, 2014). Atsakingosios inovacijos yra kompleksinè samprata, siekianti integruoti i inovacijų procesą skirtingus visuomenès narius, reikalaujanti naujų normų bei elgesio standartų dèl iškilusių naujų visuomeninių ir aplinkosaugos iššūkių. Pastaruoju metu dideja visuomenès dèmesys vadinamiesiems „Didiesiems iššūkiams“ (angl. Grand Challenges), kurie apima tokius socialinius, etinius, ekonominius bei ekologinius iššūkius kaip socialinè nelygybė, klimato kaita, vandens tarša ir kt. (Lund Declaration, 2009). Tai skatina itmones integruoti

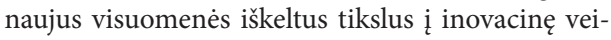
klą ir mažinti galimą neigiamą ịtaką visuomenei ir 
aplinkai. Tampa aišku, kad įmonèms būtina derinti inovacinius procesus su besikeičiančiu kontekstu, tačiau atsakingųų inovacijų tyrimuose vis dar stokojama sisteminès perspektyvos $\underset{\text { }}{\mathrm{a}}$ atsakingąsias inovacijas industrijoje.

Atsakingųjų inovacijų samprata koreliuoja su saviorganizacijos teorija, teigiančia, jog saviorganizacija yra naujos tvarkos kūrimas aukštesniame sistemos lygmenyje, inicijuotas žemesnio lygmens veikèjų sąveikų be centralizuoto valdymo (Buenstorf, 2000; Grumadaite, Jucevičius, 2017). Šiame straipsnyje siekiama saviorganizacijos perspektyva išnagrinèti atsakingąsias inovacijas industrijoje.

Atsižvelgiant $i \mathfrak{i}$ išdestytą problemą, šio tyrimo klausimas: kaip saviorganizacijos perspektyvos taikymas gali padeti geriau suprasti atsakinguju inovaciju procesus industrijoje?
Atitinkamai tyrimo tikslas yra konceptualiai pagrịsti saviorganizacijos perspektyvos taikymą atsakingosioms inovacijoms industrijoje.

Tyrimo tikslui pasiekti iškelti šie uždaviniai:

- Atskleisti socialinio konteksto vaidmeni atskingosioms inovacijoms.

- Apibrèžti atsakingưjų inovacijų kompleksiškumą industrijoje.

- Teoriškai apibrèžti bei pagrịsti saviorganizacijos perspektyvos taikymą atsakingosioms inovacijoms industrijoje.

Tyrimo metodai. Straipsnyje iškeltą tyrimo problemą teoriniame lygmenyje siekiama išspręsti remiantis mokslinès literatūros analizès metodu. Mokslinès literatūros analizè atlikta remiantis daugiausia užsienio mokslininkų atliktais tyrimais. 